\title{
Cobalt chloride treatment induces autophagic apoptosis in human glioma cells via a p53-dependent pathway
}

\author{
BOR-CHIN CHENG ${ }^{1,2^{*}}$, JUI-TAI CHEN ${ }^{3 *}$, SHUN-TAI YANG $^{4}$, CHUNG-CHING CHIO $^{5}$, \\ SHING-HWA LIU ${ }^{6}$ and RUEI-MING CHEN ${ }^{2,3,7,8}$
}

\author{
${ }^{1}$ Department of Surgery, Chi-Mei Medical Center, Tainan; ${ }^{2}$ Comprehensive Cancer Center, ${ }^{3}$ Graduate Institute of \\ Medical Sciences, Taipei Medical University, Taipei; ${ }^{4}$ Department of Neurosurgery, Shuang-Ho Hospital, \\ Taipei Medical University, New Taipei City; ${ }^{5}$ Department of Neurosurgery, Chi-Mei Medical Center, Tainan; \\ ${ }^{6}$ Institute of Toxicology, College of Medicine, National Taiwan University, Taipei; ${ }^{7}$ Anesthesiology and Health Policy \\ Research Center, Taipei Medical University Hospital, Taipei Medical University, Taipei; ${ }^{8}$ Cell Physiology and \\ Molecular Image Research Center, Wan-Fang Hospital, Taipei Medical University, Taipei, Taiwan, R.O.C.
}

Received November 17, 2016; Accepted January 13, 2017

DOI: 10.3892/ijo.2017.3861

\begin{abstract}
Malignant glioma is the most aggressive brain tumor. Hypoxic condition has been explored for killing cancer stem cells or drug-resistant tumor cells. This study investigated the effects of hypoxia on autophagic death and the possible mechanisms. Exposure of human malignant glioma U87-MG cells to cobalt chloride $\left(\mathrm{CoCl}_{2}\right)$ increased cellular hypoxia-inducible factor- $1 \alpha$ levels and concurrently decreased cell viability concentration- and time-dependently. In parallel, treatment with $\mathrm{CoCl}_{2}$ suppressed proliferation of human U87-MG cells. Autophagic cells and levels of LC3-II were concentration- and time-dependently induced in human U87-MG cells after exposure to $\mathrm{CoCl}_{2}$. However, pretreatment with 3-mehyladenine (3-MA) and chloroquine, inhibitors of cell autophagy, caused significant alleviations in $\mathrm{CoCl}_{2}-$ induced cell autophagy. In contrast, exposure to rapamycin, an inducer of cell autophagy, synergistically induced hypoxiainduced autophagy of U87-MG cells. Administration of human U87-MG cells with $\mathrm{CoCl}_{2}$ triggered caspase-3 activation and cell apoptosis. Interestingly, pretreatment with 3-MA and chloroquine remarkably suppressed $\mathrm{CoCl}_{2}$-induced caspase-3 activation and cell apoptosis. Application of p53 small interference (si)RNA into human U87-MG cells downregulated levels of this protein and simultaneously lowered hypoxiaand 3-MA-induced alterations in cell autophagy, apoptosis, and death. The hypoxia-induced autophagy and apoptosis of
\end{abstract}

Correspondence to: Dr Ruei-Ming Chen, Graduate Institute of Medical Sciences, College of Medicine, Taipei Medical University, $250 \mathrm{Wu}-\mathrm{Hsing}$ St., Taipei 110, Taiwan, R.O.C.

E-mail:rmchen@tmu.edu.tw

*Contributed equally

Key words: malignant glioma, hypoxia, p53, autophagy, autophagic apoptosis
DBTRG-05MG cells were significantly lowered by 3-MA pretreatment and p53 knockdown. Therefore, the present study shows that $\mathrm{CoCl}_{2}$ treatment can induce autophagy of human glioma cells and subsequent autophagic apoptosis via a p53-dependent pathway. Hypoxia-induced autophagic apoptosis may be applied as a therapeutic strategy for treatment of glioma patients.

\section{Introduction}

Gliomas are primary solid tumors of the brain and may arise from transformations of three major types of glial cells, including astrocytes, oligodendrocytes, and ependymal cells (1). According to the World Health Organization grading system, gliomas are classed into low-grade tumors (grades I and II) and high-grade tumors (grades III and IV). Glioblastoma multiforme (GBM), classified as a malignant grade IV glioma, is the most aggressive brain tumor (2). The location of tumor occurrence in the brain and the high variability in genetic abnormalities are two major risk factors existing in malignant gliomas (3). In addition, malignant gliomas present unique features of rapid growth and high migration that consequently result in poor prognoses and high mortality rates in GBM patients (4). In the clinic, the median overall survival time and the 5-year survival rate of GBM patients are $~ 10.2-14.6$ months and 5\%, respectively (5). Therefore, discovering more-effective therapeutic strategies for glioma patients remains a challenge today.

Hypoxia is a condition in which a tissue is not satisfactorily oxygenated. Under hypoxic stimulation, tissues/cells can be driven either to survive by expanding the glycolysis rate or to death via a programmed pathway (6). In contrast, hypoxic microenvironments inside cancers are able to promote tumor growth, angiogenesis, and invasion (7). Brain hypoxia frequently occurs in brain neoplasms and traumatic brain injuries and is furthermore recognized as a major potential cause of secondary injury in neurologically critically ill patients (8). In hypoxic conditions, hypoxia-inducible factor (HIF)-1 $\alpha$, 
a transcription factor, is highly induced and essentially participates in regulating cell survival or death $(9,10)$. HIF-1 $\alpha$ functions by binding to specific recognition sequences in the genome to stimulate transcriptions of certain genes involved in various metabolic pathways that are necessary for cells in response to an oxygen-poor environment $(11,12)$. Joseph et al, reported that an HIF- $1 \alpha$-mediated signaling axis contributes to a hypoxia-induced mesenchymal shift, migration, and invasion in malignant gliomas (13). Nonetheless, a previous study showed the positive roles of HIF-1 $\alpha$ in hypoxia-induced glioblastoma cell death (14). Therefore, hypoxia has bidirectional roles in controlling glioma growth and death.

Autophagy is a preserved progression inside cells that uses double-membrane vesicles, called autophagosomes, to deliver cytoplasmic contents to lysosomes for degradation of long-lived and misfolded proteins, damaged and dysfunctional organelles, and foreign particles $(15,16)$. Microtubule-associated protein light chain 3 (LC3), a consistent marker of autophagy, is important for the progression of autophagy because it is essential for the formation of autophagosomes (17). Autophagy is critical for maintaining homeostasis in certain diseases, including neurodegeneration, cancers and aging $(15,18)$. Recently, induction of autophagy by drugs was considered a novel therapeutic strategy for treating GBM cancer stem cells and temozolomide (TMZ)-resistant glioma cells (19). Dolma et al showed that inhibition of the D4 dopamine receptor delays autophagic flux, proliferation, and survival of glioblastoma stem cells (20). In our lab, we proved the effects of honokiol, a polyphenol, on initiating autophagy and subsequent cell death in human malignant gliomas in vitro and in vivo (21). Recently, induction of hypoxia was investigated as an effective treatment strategy $(19,22)$. However, autophagic cells can survive or undergo apoptosis $(23,24)$. Our previous studies showed honokiol-induced autophagic death in neuroblastomas and gliomas $(21,25)$. p53, a tumor suppressor protein, is involved in regulating cell survival, autophagy and apoptosis (26). In this study, we investigated the effects of hypoxia on autophagy and apoptosis of human malignant glioma cells and the possible mechanisms.

\section{Materials and methods}

Cell culture and drug treatment. Human glioma U87-MG cells and DBTRG-05MG cells purchased from American Type Culture Collection (Manassas, VA, USA) were cultured in minimum essential medium (MEM; Gibco-BRL Life Technologies, Grand Island, NY, USA) supplemented with $10 \%$ fetal bovine serum (FBS), $2 \mathrm{mM}$ L-glutamine, $100 \mathrm{IU} / \mathrm{ml}$ penicillin, $100 \mathrm{mg} / \mathrm{ml}$ streptomycin, $1 \mathrm{mM}$ sodium pyruvate, and $1 \mathrm{mM}$ non-essential amino acids at $37^{\circ} \mathrm{C}$ in a humidified atmosphere of $5 \% \mathrm{CO}_{2}$. Cells were grown to confluence before drug treatment. Cobalt chloride $\left(\mathrm{CoCl}_{2}\right)$ purchased from Sigma (St. Louis, MO, USA) was freshly dissolved in in 1X phosphate-buffered saline (PBS; 0.14 M NaCl, $2.6 \mathrm{mM}$ $\mathrm{KCl}, 8 \mathrm{mM} \mathrm{Na}_{2} \mathrm{HPO}_{4}$ and $1.5 \mathrm{mM} \mathrm{KH}_{2} \mathrm{PO}_{4}$ ). Human U87-MG cells were exposed to different concentrations of $\mathrm{CoCl}_{2}$ and/or other agents indicated in the text for various intervals. Control cells received PBS only. 3-Methyladenine (3-MA) and chloroquine, inhibitors of cell autophagy, and rapamycin (Rapa), an inducer of cell autophagy, were purchased from Sigma. To determine the effects of 3-MA, chloroquine, and Rapa on
$\mathrm{CoCl}_{2}$-induced autophagy, caspase- 3 activation, cell apoptosis, and cell death, the glioma cells were pretreated with $1 \mathrm{mM}$ 3-MA, $20 \mu \mathrm{M}$ chloroquine, or $0.5 \mu \mathrm{M}$ Rapa for $1 \mathrm{~h}$ and then exposed to $\mathrm{CoCl}_{2}$.

Assays of cell morphology and cell viability. The toxicity of hypoxia to human glioma U87-MG cells was determined by analyses of cell morphology and viability as described previously (12). Briefly, U87-MG cells $\left(10^{4}\right.$ cells/well) were seeded in 96-well tissue culture plates overnight. After drug treatment, U87-MG cells were cultured in new medium containing $0.5 \mathrm{mg} / \mathrm{ml} \mathrm{3-(4,5-dimethylthiazol-2-yl)-2,5-diphenyltetrazo-}$ lium bromide for a further $3 \mathrm{~h}$. The blue formazan products in U87-MG cells were dissolved in dimethyl sulfoxide and spectrophotometrically measured at a wavelength of $550 \mathrm{~nm}$. Cell morphologies were observed and photographed using a light microscope (Nikon, Tokyo, Japan).

Cell proliferation assay. The effect of hypoxia on cell proliferation was analyzed by measuring the incorporation of bromodeoxyuridine (BrdU) into genomic DNA as described previously (27). Human glioma U87-MG cells were seeded at $3 \times 10^{3}$ cells/well in 96-well microtiter plates. After drug treatment, $10 \mathrm{mM}$ BrdU was added to the culture medium for incorporation into the DNA of replicating cells. After $2 \mathrm{~h}$ of incubation, cells were fixed in $4 \%$ paraformaldehyde. BrdU incorporation was determined by a cell proliferation enzyme-linked immunosorbent assay (ELISA) BrdU kit (Roche, Mannheim, Germany).

Assay of cell autophagy. Cell autophagy was assayed by quantifying acidic vesicular organelles using flow cytometry as described previously (25). After drug treatment, human glioma U87-MG and DBTRG-05MG cells $\left(10^{5}\right)$ were treated with $1 \mu \mathrm{g} / \mathrm{ml}$ of acridine orange (AO) for $20 \mathrm{~min}$. Then, the cells were collected in phenol red-free MEM. The green and red fluorescence of AO in cells were measured with a flow cytometer (Becton-Dickinson, San Jose, CA, USA). Fluorescent intensities were quantified with the aid of CellQuest software (Becton-Dickinson). A fluorescent microscope (Nikon) was used to observe and photograph cells with fluorescent signals.

Assay of caspase-3 activity. Caspase-3 activity was determined using a fluorometric substrate assay kit as described previously (28). Briefly, after drug administration, human glioma U87-MG cells were lysed using a buffer containing $1 \%$ Nonidet P-40, $200 \mathrm{mM} \mathrm{NaCl}, 20 \mathrm{mM}$ Tris/HCl (pH 7.4), $10 \mathrm{mg} / \mathrm{ml}$ leupeptin, $0.27 \mathrm{U} / \mathrm{ml}$ aprotinin, and $100 \mathrm{~mm}$ PMSF. Cell extracts $(25 \mathrm{mg}$ of total protein) were incubated with $50 \mathrm{mM}$ of a specific fluorogenic peptide substrate in $200 \mathrm{ml}$ of a cell-free system buffer composed of $10 \mathrm{mM}$ HEPES (pH 7.4), $220 \mathrm{mM}$ mannitol, $68 \mathrm{mM}$ sucrose, $2 \mathrm{mM} \mathrm{NaCl}, 2.5 \mathrm{mM}$ $\mathrm{KH}_{2} \mathrm{PO}_{4}, 0.5 \mathrm{mM}$ EGTA, $2 \mathrm{mM} \mathrm{MgCl}_{2}, 5 \mathrm{mM}$ pyruvate, $0.1 \mathrm{mM}$ PMSF, and $1 \mathrm{mM}$ dithiothreitol. The peptide substrate for the caspase-3 enzyme assay was DEVD. The peptide was conjugated to 7-amino-4-trifluoromethyl coumarin for fluorescence detection. Intensities of the fluorescent products were measured with a spectrometer.

Quantification of apoptotic cells. Apoptosis of human glioma U87-MG and DBTRG-05MG cells was determined using 
A

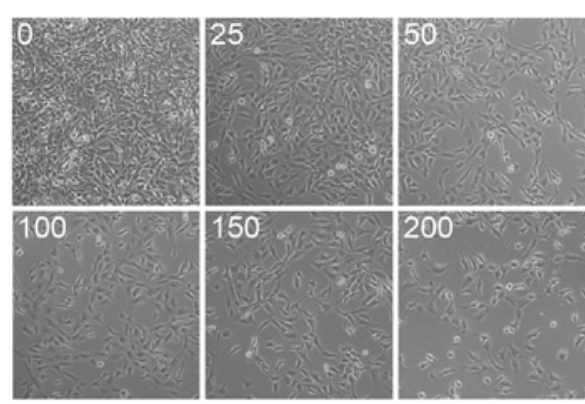

C

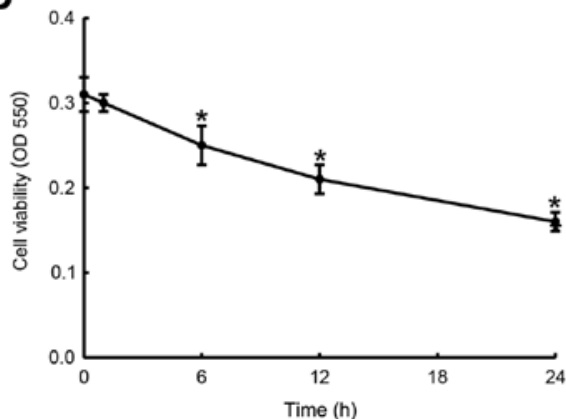

B

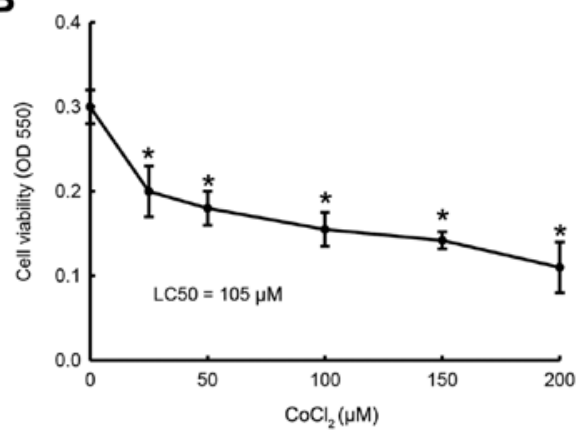

E
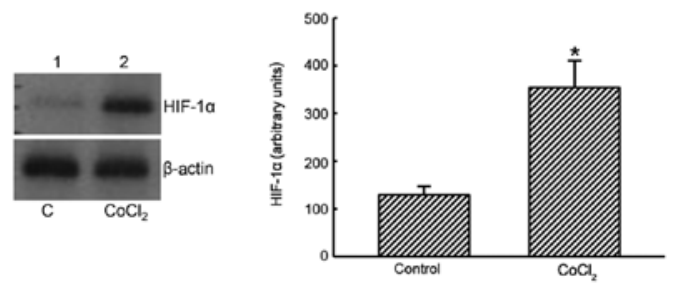

Figure 1. Effects of cobalt chloride $\left(\mathrm{CoCl}_{2}\right)$ on cell morphology and cell viability. Human glioma U87-MG cells were treated with $25,50,100,150$ and $200 \mu \mathrm{M}$ $\mathrm{CoCl}_{2}$ for $24 \mathrm{~h}$ (A and B) or with $100 \mu \mathrm{M} \mathrm{CoCl}_{2}$ for 1, 6, 12 and $24 \mathrm{~h}$ (C). Cell morphology was observed and photographed using a light microscope (A). Cell viability was assayed using a colorimetric method (B and C). Human U87-MG cells were exposed to $100 \mu \mathrm{M} \mathrm{CoCl}_{2}$ for $24 \mathrm{~h}$, and cellular proteins were prepared. Levels of hypoxia-inducible factor (HIF)- $1 \alpha$ were immunodetected (D, left-top panel). $\beta$-actin was analyzed as the internal control (left-bottom panel). These protein bands were quantified and statistically analyzed ( $D$, right panel). Each value represents the mean \pm SEM for $n=6$. ${ }^{*} p<0.05$, value significantly differed from the control group.

propidium iodide (PI) to detect DNA injury in nuclei according to a previously described method (29). Briefly, after drug administration, human glioma U87-MG cells were harvested and fixed in cold $80 \%$ ethanol. Following centrifugation and washing, fixed cells were stained with PI and analyzed using a FACScan flow cytometer (Becton-Dickinson).

Immunoblot analyses. Protein analyses were performed according to a previously described assay (30). Briefly, after drug treatment, cell lysates were prepared in iced radioimmunoprecipitate test buffer $(25 \mathrm{mM}$ Tris $\mathrm{HCl}, 0.1 \%$ sodium dodecylsulfate (SDS). $1 \%$ Triton X-100, $1 \%$ sodium deoxycholate, $0.15 \mathrm{M} \mathrm{NaCl}$, and $1 \mathrm{mM}$ EDTA). Protein concentrations were measured using a bicinchonic acid protein assay kit (Pierce, Rockford, IL, USA). The protein (50 $\mu \mathrm{g} / \mathrm{well})$ was subjected to SDS polyacrylamide gel electrophoresis (PAGE), and transferred to nitrocellulose membranes. After blocking, LC3-I, LC3-II, HIF-1 $\alpha$, and p53 were immunodetected using rabbit polyclonal antibodies or mouse monoclonal antibodies against related proteins (Cell Signaling, Danvers, MA, USA). Cellular $\beta$-actin protein was immunodetected using a mouse monoclonal antibody against mouse $\beta$-actin (Sigma) as the internal control. These protein bands were quantified using a digital imaging system (UVtec, Cambridge, UK).

p53 knockdown. Translation of p53 messenger (m)RNA in human glioma U87-MG and DBTRG-05MG cells was knocked-down using an RNA interference (RNAi) method following a small interfering (si)RNA transfection protocol provided by Santa Cruz Biotechnology (Santa Cruz, CA, USA) as described previously (31). p53 siRNA was purchased from Santa Cruz Biotechnology, and is a pool of three targetspecific 20-25-nt siRNAs designed to suppress p53 expression. Scrambled siRNA, purchased from Santa Cruz Biotechnology, contained non-targeting 20-25-nt siRNA and was applied to control cells as a negative standard. Briefly, after culturing U87-MG cells in antibiotic-free MEM at $37^{\circ} \mathrm{C}$ in a humidified atmosphere of $5 \% \mathrm{CO}_{2}$ for $24 \mathrm{~h}$, the siRNA duplex solution, which was diluted in an siRNA transfection medium (Santa Cruz Biotechnology), was added to human glioma cells. After transfection with scrambled or p53 siRNA for $24 \mathrm{~h}$, the medium was replaced with normal MEM, and the cells were treated with $\mathrm{CoCl}_{2}$.

Statistical analysis. Statistical differences between the control and drug-treated groups were considered significant when the p-value of Duncan's multiple-range test was $<0.05$. Statistical analysis between drug-treated groups was carried out using a two-way analysis of variance (ANOVA).

\section{Results}

Cell morphology, cell viability, and cellular HIF-1 $\alpha$ levels were analyzed to determine the effects of $\mathrm{CoCl}_{2}$ on inducing of hypoxia and cytotoxicity in human glioma U87-MG cells (Fig. 1). Exposure of human U87-MG cells to $25 \mu \mathrm{M} \mathrm{CoCl}_{2}$ 

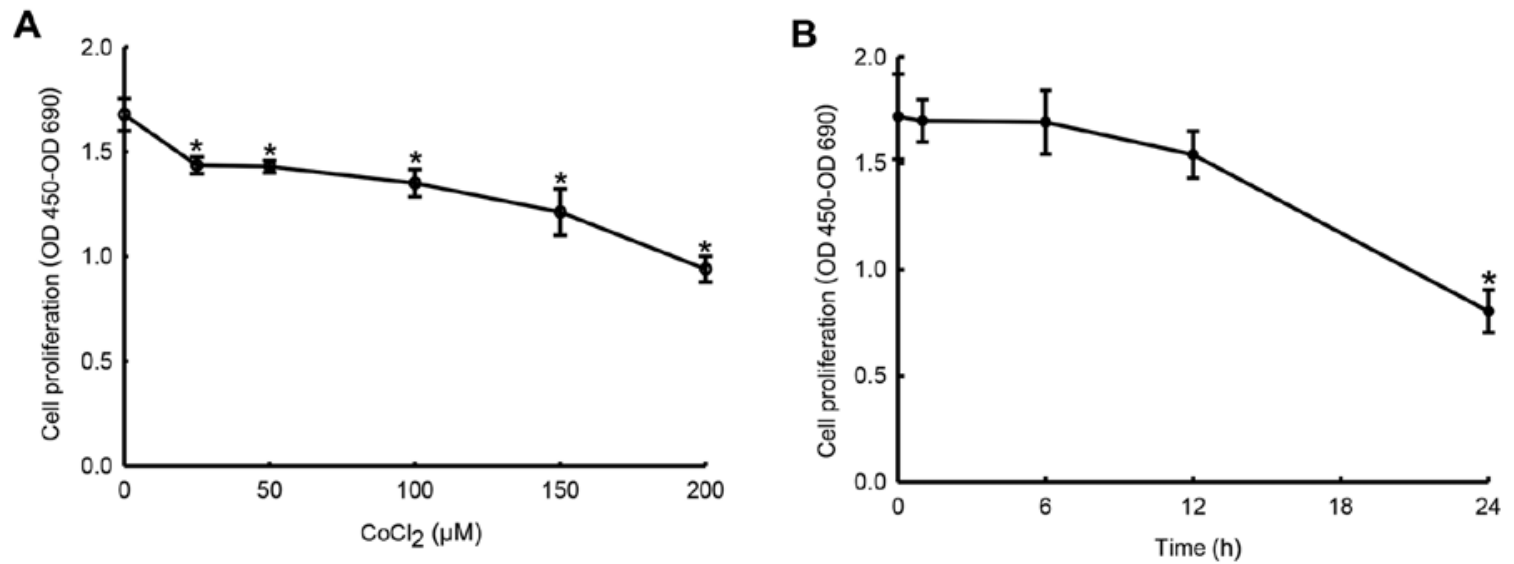

Figure 2. Effects of cobalt chloride $\left(\mathrm{CoCl}_{2}\right)$ on cell proliferation. Human glioma U87-MG cells were treated with $25,50,100,150$ and $200 \mu \mathrm{M} \mathrm{CoCl}{ }_{2}$ for $24 \mathrm{~h}$ (A) or with $100 \mu \mathrm{M} \mathrm{CoCl}_{2}$ for 1,6,12 and $24 \mathrm{~h}$ (B). Cell proliferation was analyzed using a thymidine incorporation assay. Each value represents the mean \pm SEM for $n=6 .{ }^{*} p<0.05$, value significantly differed from the control group.

A

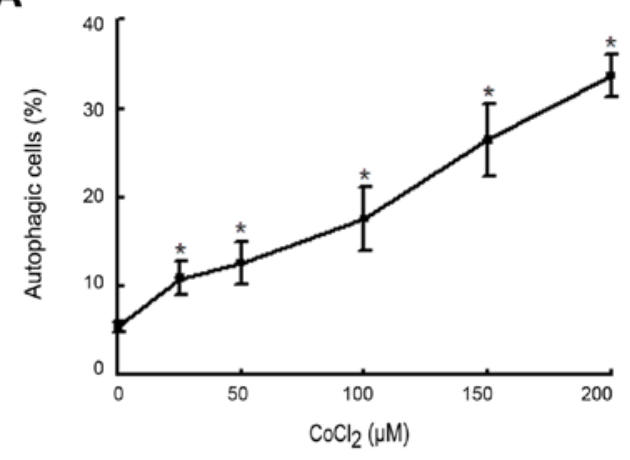

C

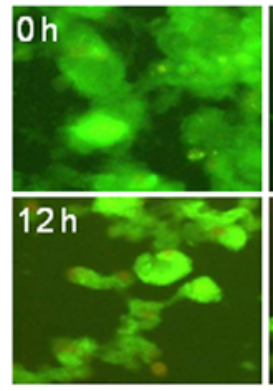

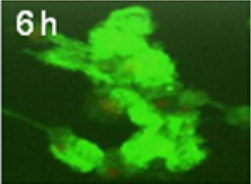

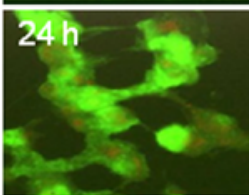

B

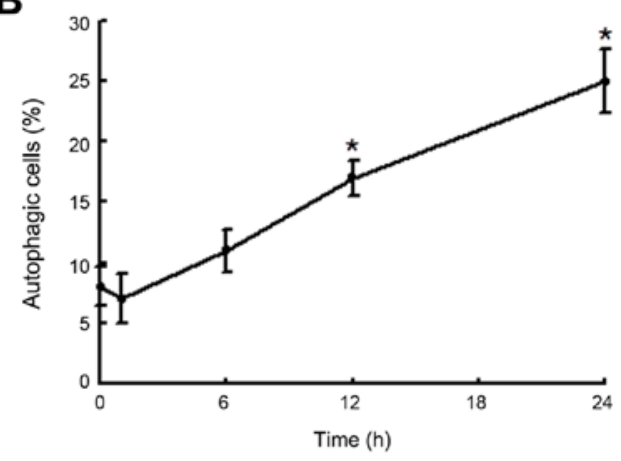

D

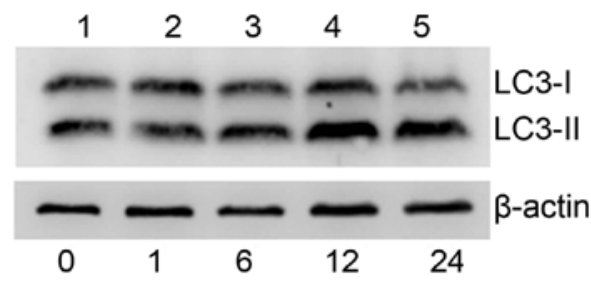

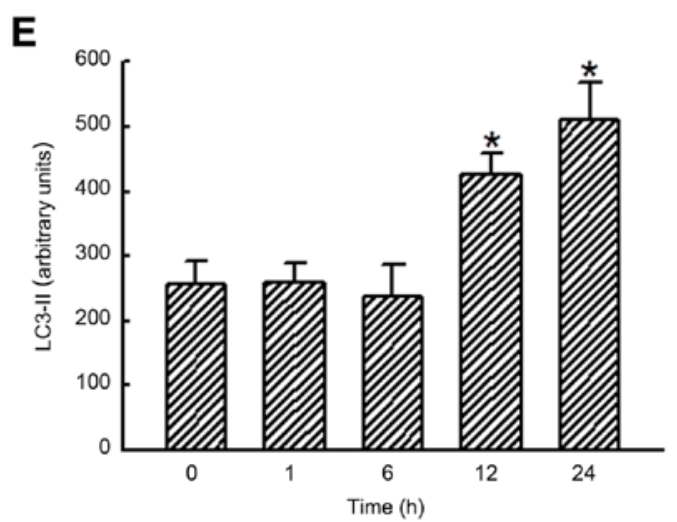

Figure 3. Effects of cobalt chloride $\left(\mathrm{CoCl}_{2}\right)$ on cell autophagy and levels of light chain 3-I (LC3-I) and LC3-II. Human glioma U87-MG cells were treated with 25, 50, 100, 150 and $200 \mu \mathrm{M} \mathrm{CoCl}_{2}$ for $24 \mathrm{~h}$ (A) or with $100 \mu \mathrm{M} \mathrm{CoCl}_{2}$ for 1,6, 12 and $24 \mathrm{~h}$ (B-D). Cell autophagy was analyzed using a flow cytometer (A and B). Cells with fluorescent signals were observed and photographed with a fluorescent microscope at x200 (C). Levels of LC3-I and LC3-II were immunodetected (D, top panel). $\beta$-actin was analyzed as the internal control (bottom panel). These protein bands were quantified and statistically analyzed (E). Each value represents the mean \pm SEM for $n=6$. ${ }^{*} \mathrm{p}<0.05$, value significantly differed from the control group. 
A

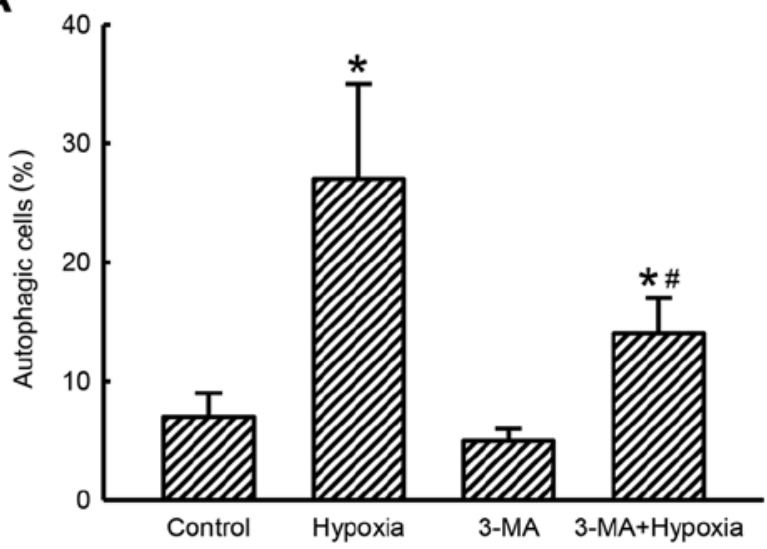

B

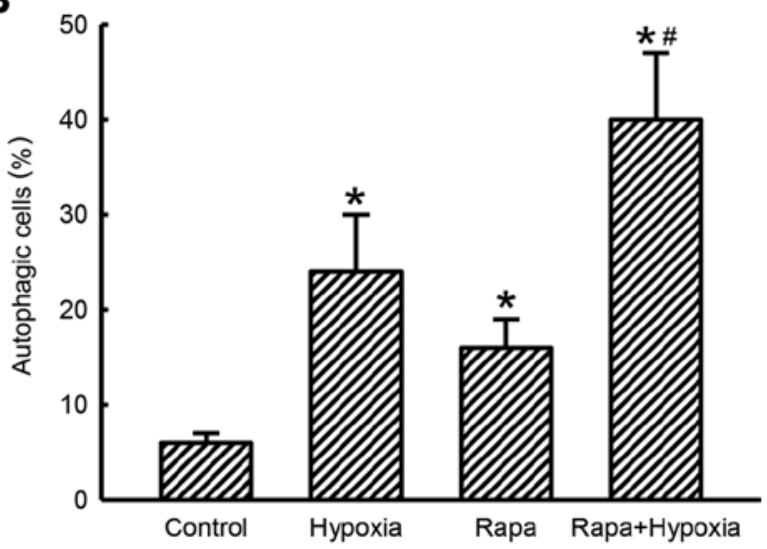

Figure 4. Effects of 3-methyladenine (3-MA) and rapamycin (Rapa) on cobalt chloride $\left(\mathrm{CoCl}_{2}\right)$-induced cell autophagy. Human glioma U87-MG cells were pretreated with $1 \mathrm{mM} 3-\mathrm{MA}$, an inhibitor of cell autophagy (A), or $0.5 \mu \mathrm{M}$ Rapa, an inducer of cell autophagy (B), for $1 \mathrm{~h}$ and then exposed to $100 \mu \mathrm{M} \mathrm{CoCl}$ for another $24 \mathrm{~h}$ (hypoxia). Cell autophagy was analyzed using flow cytometry. Each value represents the mean \pm SEM for $n=6$. ${ }^{* \#} \mathrm{p}<0.05$, values significantly differed from the control and hypoxia-treated groups, respectively.

for $24 \mathrm{~h}$ decreased cell numbers (Fig. 1A). After exposure to $50,100,150$ and $200 \mu \mathrm{M} \mathrm{CoCl}_{2}$ for $24 \mathrm{~h}$, cell numbers timedependently decreased. Treatment of human U87-MG cells with $25 \mu \mathrm{M} \mathrm{CoCl}_{2}$ for $24 \mathrm{~h}$ caused a $31 \%$ reduction in cell viability (Fig. 1B). When the administered concentrations of $\mathrm{CoCl}_{2}$ reached 50, 100, 150 and $200 \mu \mathrm{M}$, cell viabilities were diminished by $36,45,52$ and $63 \%$, respectively. Exposure of U87-MG cells to $100 \mu \mathrm{M} \mathrm{CoCl}_{2}$ for $1 \mathrm{~h}$ did not influence cell viability (Fig. 1C). In contrast, viabilities of U87-MG cells were lowered by 19,30 and $47 \%$ after $\mathrm{CoCl}_{2}$ treatment for 6,12 and $24 \mathrm{~h}$, respectively. Low levels of HIF-1 $\alpha$ were detected in untreated U87-MG cells (Fig. 1D, top panel, lane 1). However, exposure to $100 \mu \mathrm{M} \mathrm{CoCl}{ }_{2}$ for $24 \mathrm{~h}$ obviously enhanced amounts of cellular HIF-1 $\alpha$ (lane 2 ). $\beta$-actin was analyzed as the internal control (bottom panel). These protein bands were quantified and statistically analyzed (Fig. 1E). Treatment with $100 \mu \mathrm{M} \mathrm{CoCl}_{2}$ for $24 \mathrm{~h}$ significantly increased levels of HIF-1 $\alpha$ in human U87-MG cells by 2.7-fold.

To decide the effects of $\mathrm{CoCl}_{2}$ treatment on cell proliferation, a BrdU incorporation assay was conducted (Fig. 2). Exposure of human glioma U87-MG cells to $25 \mu \mathrm{M} \mathrm{CoCl}_{2}$ for $24 \mathrm{~h}$ caused a $15 \%$ diminution in cell proliferation (Fig. 2A). In comparison, $\mathrm{CoCl}_{2}$ at $50,100,150$ and $200 \mu \mathrm{M}$ suppressed proliferation of human U87-MG cells by 17, 20, 28 and 42\%, respectively. Exposure of human U87-MG cells to $100 \mu \mathrm{M}$ $\mathrm{CoCl}_{2}$ for 1,6 , and $12 \mathrm{~h}$ did not affect cell proliferation (Fig. 2B). Nonetheless, treatment with $\mathrm{CoCl}_{2}$ for $24 \mathrm{~h}$ caused a significant $49 \%$ decline in the proliferation of human U87-MG cells.

Autophagic cells and cellular LC3-II levels were examined in order to determine the effects of $\mathrm{CoCl}_{2}$ treatment on autophagy of human U87-MG cells (Fig. 3). Treatment with $25 \mu \mathrm{M} \mathrm{CoCl}_{2}$ for $24 \mathrm{~h}$ induced $16 \%$ of human U87-MG cells to undergo autophagy (Fig. 3A). Fractions of autophagic cells in human U87-MG cells were significantly augmented to 19, 28,41 and $52 \%$ following respective exposure to $50,100,150$ and $200 \mu \mathrm{M} \mathrm{CoCl}_{2}$ for $24 \mathrm{~h}$. Treatment of human U87-MG cells with $100 \mu \mathrm{M} \mathrm{CoCl}_{2}$ for 1 and $6 \mathrm{~h}$ did not change cell autophagy (Fig. 3B). In contrast, after exposure for 12 and
$24 \mathrm{~h}, \mathrm{CoCl}_{2}$ administration induced cell autophagy by 17 and $25 \%$, respectively. Staining with AO revealed that exposure of human U87-MG cells to $\mathrm{CoCl}_{2}$ for $6 \mathrm{~h}$ did not change the proportion of cells with acidic vesicular organelles (Fig. 3C). In comparison, after exposure to $\mathrm{CoCl}_{2}$ for 12 or $24 \mathrm{~h}$, proportions of human U87-MG cells stained with AO were augmented. Exposure of human U87-MG cells to $100 \mu \mathrm{M}$ $\mathrm{CoCl}_{2}$ for 1 or $6 \mathrm{~h}$ did not affect levels of the LC3-II protein (Fig. 3D, top panel, lanes 2 and 3). However, after treatment with $\mathrm{CoCl}_{2}$ for 12 or $24 \mathrm{~h}$, amounts of LC3-II in U87-MG cells were obviously augmented (lanes 4 and 5 ). $\beta$-actin was analyzed as the internal control (bottom panel). These protein bands were quantified and statistically analyzed (Fig. 3E). Exposure of human U87-MG cells to $100 \mu \mathrm{M} \mathrm{CoCl}_{2}$ for 12 or $24 \mathrm{~h}$ led to 72 and $98 \%$ increases in amounts of the LC3-II protein.

To confirm $\mathrm{CoCl}_{2}$-induced autophagy, 3-MA, an inhibitor of autophagy, and Rapa, an inducer of autophagy, were applied to human U87-MG cells (Fig. 4). Treatment of human U87-MG cells with $100 \mu \mathrm{M} \mathrm{CoCl}_{2}$ for $24 \mathrm{~h}$ induced $28 \%$ of glioma cells to undergo autophagy (Fig. 4A). Pretreatment with 3-MA alone did not influence cell autophagy but significantly decreased hypoxia-induced cell autophagy by $68 \%$. In contrast, pretreatment with Rapa alone triggered $16 \%$ of human U87-MG cells to undergo autophagy (Fig. 4B). Interestingly, pretreatment with Rapa synergistically induced hypoxia-induced cell autophagy by $40 \%$.

Caspase-3 activity and apoptotic cells were analyzed to determine the effects of $\mathrm{CoCl}_{2}$-induced autophagy on cell apoptosis (Fig. 5). Treatment of human U87-MG cells with $100 \mu \mathrm{M} \mathrm{CoCl}{ }_{2}$ for 1 and $6 \mathrm{~h}$ did not influence caspase- 3 activity (Fig. 5A). When the treatment time intervals reached 12 and $24 \mathrm{~h}$, caspase-3 activities were significantly augmented in human U87-MG cells by 2.5- and 3.8-fold, respectively. Administration of $100 \mu \mathrm{M} \mathrm{CoCl}_{2}$ to human U87-MG cells for 1 and $6 \mathrm{~h}$ did not affect cell apoptosis (Fig. 5B). Nevertheless, after exposure to $\mathrm{CoCl}_{2}$ for 12 or $24 \mathrm{~h}$, the fractions of human U87-MG cells that underwent apoptosis were significantly increased to 24 and $37 \%$. Pretreatment of human U87-MG cells 
A

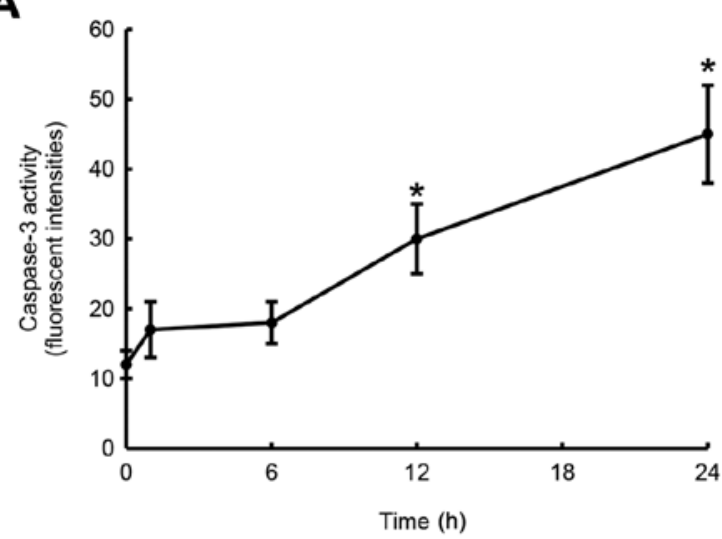

C

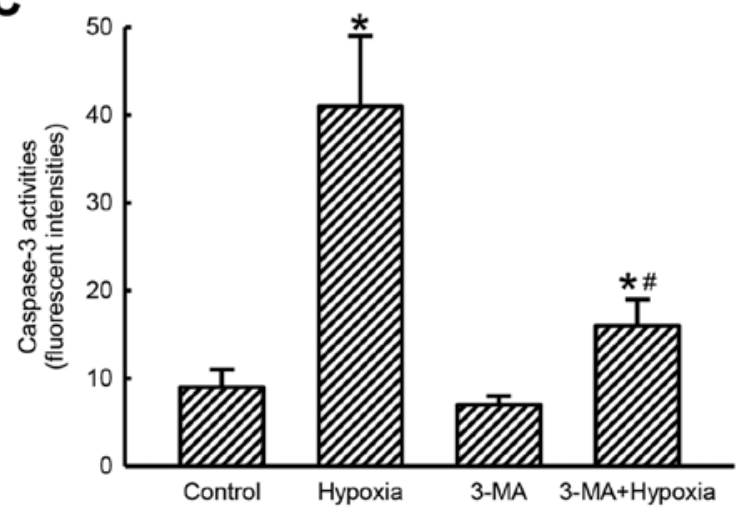

B

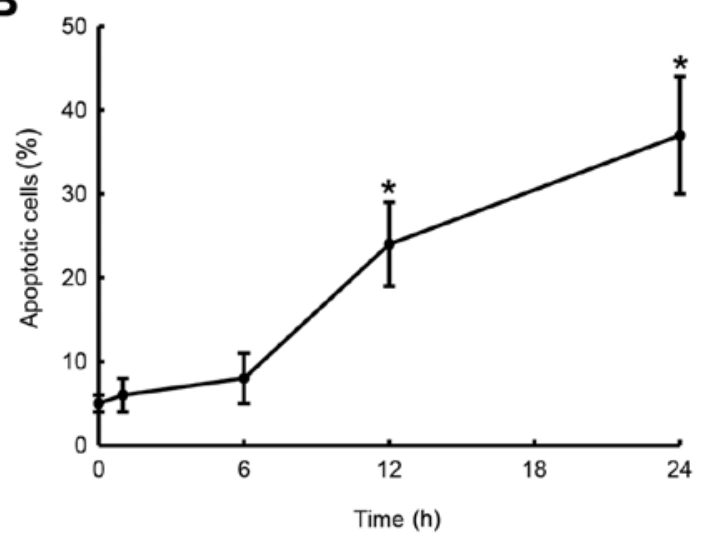

D

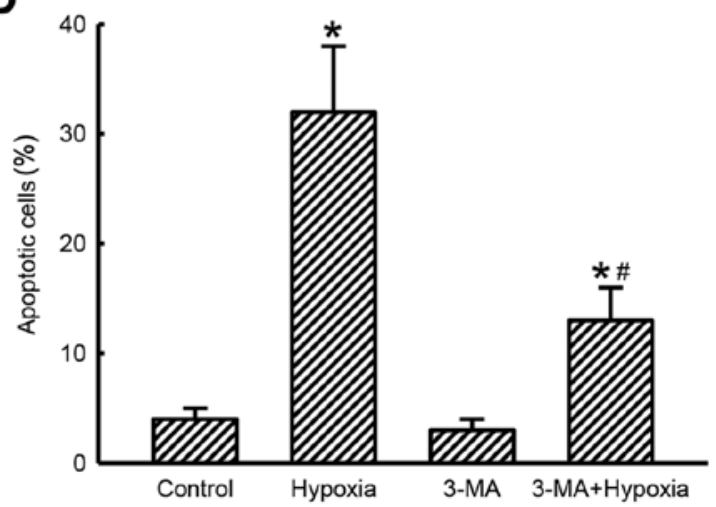

Figure 5. Effects of cobalt chloride $\left(\mathrm{CoCl}_{2}\right)$ and 3-methyladenine (3-MA) on caspase-3 activity and cell apoptosis. Human glioma U87-MG cells were treated with $100 \mu \mathrm{M} \mathrm{CoCl}_{2}$ for 1, 6, 12 and $24 \mathrm{~h}$. Caspase-3 activity was analyzed using a fluorometric substrate assay (A). Cell apoptosis was assayed using a flow cytometer (B). Human glioma U87-MG cells were pretreated with $1 \mathrm{mM} 3$-MA and exposed to $100 \mu \mathrm{M} \mathrm{CoCl}_{2}$ for another $24 \mathrm{~h}$ (hypoxia). Caspase-3 activity (C) and cell apoptosis (D) were analyzed. Each value represents the mean \pm SEM for $n=6$. ${ }^{*, \#} \mathrm{p}<0.05$, values significantly differed from the control and hypoxia-treated groups, respectively.

Table I. Effects of chloroquine (CLQ) on cobalt chloride $\left(\mathrm{CoCl}_{2}\right)$-induced insults to human glioma cells.

\begin{tabular}{lcccc}
\hline & Cell viability $\left(\mathrm{OD}_{550}\right)$ & Cell autophagy $(\%)$ & Caspase-3 activity (FI) & Apoptotic cells $(\%)$ \\
\hline Control & $0.412 \pm 0.089$ & $6 \pm 1$ & $11 \pm 3$ & $5 \pm 1$ \\
$\mathrm{CoCl}_{2}$ & $0.133 \pm 0.048^{\mathrm{a}}$ & $29 \pm 7^{\mathrm{a}}$ & $41 \pm 8^{\mathrm{a}}$ & $39 \pm 7^{\mathrm{a}}$ \\
$\mathrm{CLQ}$ & $0.402 \pm 0.102$ & $5 \pm 1$ & $9 \pm 2$ & $6 \pm 2$ \\
CLQ+hypoxia & $0.268 \pm 0.069^{\mathrm{a}, \mathrm{b}}$ & $14 \pm 3^{\mathrm{a}, \mathrm{b}}$ & $16 \pm 4^{\mathrm{a}, \mathrm{b}}$ & $19 \pm 4^{\mathrm{a}, \mathrm{b}}$ \\
\hline
\end{tabular}

Human glioma U87-MG cells were pretreated with $20 \mu \mathrm{M}$ CLQ, an inhibitor of cell autophagy, for $1 \mathrm{~h}$ and then exposed to $100 \mu \mathrm{M} \mathrm{CoCl}_{2}$ for another $24 \mathrm{~h}$ (hypoxia). Cell viability was assayed using a colorimetric method. Autophagic and apoptotic cells were quantified using flow cytometry. Caspase- 3 activity was analyzed with a fluorometric substrate assay. Each value represents the mean $\pm \mathrm{SEM}$ for $\mathrm{n}=6$. $^{\mathrm{a}, \mathrm{b}} \mathrm{p}<0.05$, Values significantly differed from the control and $\mathrm{CoCl}_{2}$-treated groups, respectively. FI, fluorescent intensities.

with 3-MA alone did not change caspase-3 activity (Fig. 5C) or cell apoptosis (Fig. 5D). In contrast, pretreatment with 3-MA caused significant 61 and 58\% alterations in hypoxia-induced caspase-3 activation and cell apoptosis, respectively (Fig. 5C and D).

Chloroquine, another inhibitor of cell autophagy, was further applied to human U87-MG cells to confirm $\mathrm{CoCl}_{2}$ - induced cell insults (Table I). Pretreatment of human U87-MG cells with chloroquine did not affect cell viability, cell autophagy, caspase-3 activity, or cell apoptosis. In contrast, chloroquine pretreatment caused significant 51, 52, 61 and $51 \%$ decreases in $\mathrm{CoCl}_{2}$-induced alterations in cell viability, autophagic cells, caspase-3 activation, and apoptotic cells, respectively (Table I). 
A
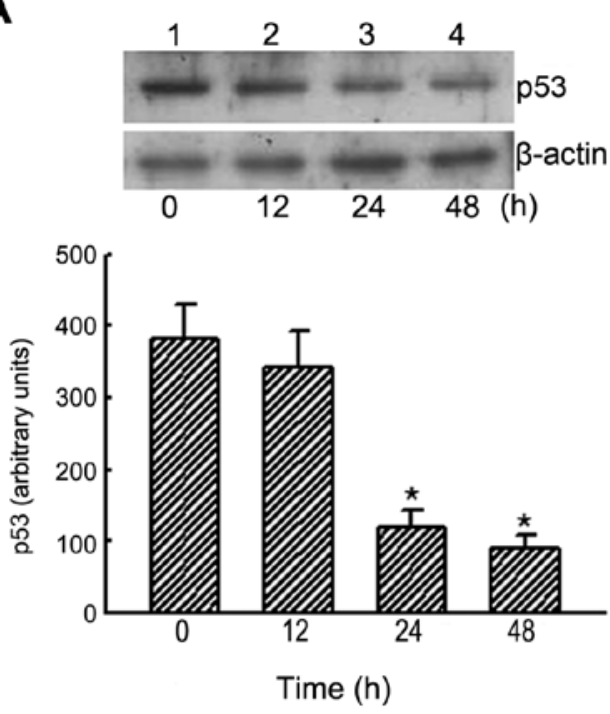

C

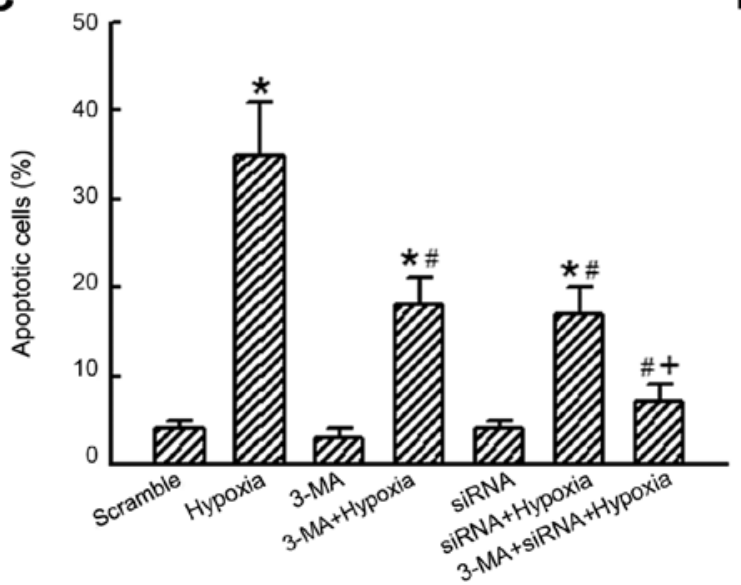

B

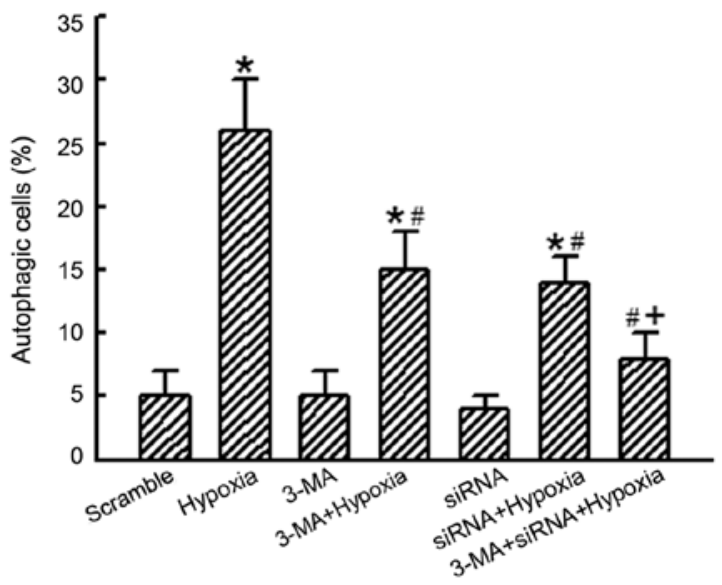

D

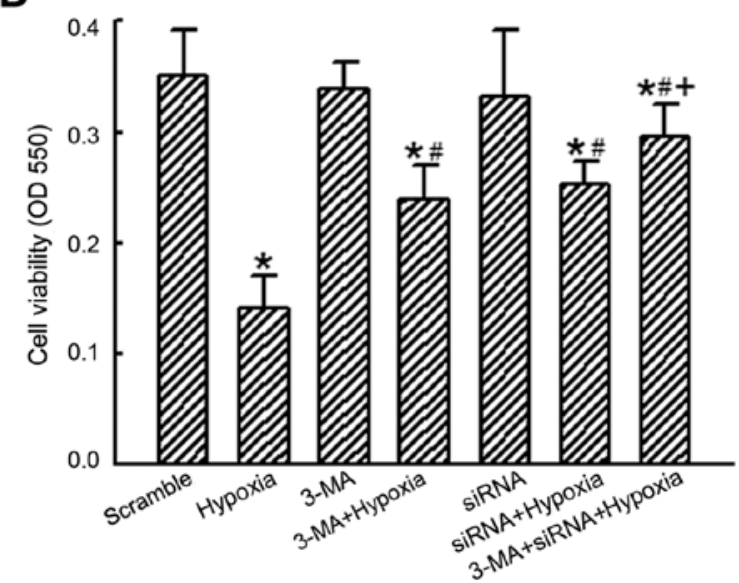

Figure 6. Roles of p53 in cobalt chloride $\left(\mathrm{CoCl}_{2}\right)$-induced cell autophagy, apoptosis, and viability. Human glioma U87-MG cells were exposed to p53 siRNA (siRNA) for 6, 12 and $24 \mathrm{~h}$. Scrambled siRNA was applied into control cells as the negative control (scramble). Levels of p53 were immunodetected, and $\beta$-actin was analyzed as the internal control (A, top panel). These protein bands were quantified and statistically analyzed (bottom panel). U87-MG cells were pretreated with p53 siRNA (siRNA) and 3-methyladenine (3-MA) and then exposed to $100 \mu \mathrm{M} \mathrm{CoCl}_{2}$ for another $24 \mathrm{~h}$ (hypoxia). Cell autophagy (B) and cell apoptosis $(C)$ were determined using flow cytometry. Cell viability was assayed using a colorimetric method (D). Each value represents the mean \pm SEM for $\mathrm{n}=6{ }^{*}, *,+, \mathrm{p}<0.05$, values significantly differed from the control, hypoxia-, and 553 siRNA-treated groups, respectively.

RNAi was applied to human U87-MG cells to determine the roles of 553 in $\mathrm{CoCl}_{2}$-induced autophagic death (Fig. 6). Application of p53 siRNA to human U87-MG cells for $12 \mathrm{~h}$ did not affect levels of p53 (Fig. 6A, top panel, lane 2). However, after exposure to p53 siRNA for 24 or $48 \mathrm{~h}$, amounts of p53 in human U87-MG cells were significantly decreased (lanes 3 and 4). $\beta$-actin was analyzed as the internal control (top panel). These protein bands were quantified and statistically analyzed (bottom panel). Application of p53 siRNA to human U87-MG cells for 24 or $48 \mathrm{~h}$ caused significant 69 and $77 \%$ reductions in levels of p53, respectively. Exposure to hypoxia induced autophagy of $28 \%$ of human U87-MG cells (Fig. 6B). Pretreatment with 3-MA and p53 siRNA did not affect cell autophagy but significantly alleviated hypoxia-induced autophagy of human U87-MG cells. Co-treatment with 3-MA and p53 siRNA synergistically lowered hypoxia-induced cell autophagy (Fig. 6B). At the same time, pretreatment of human U87-MG cells with a combination of 3-MA and p53 siRNA caused noteworthy alleviations of hypoxia-induced cell apoptosis and cell death (Fig. 6C and D).

To confirm the roles of $\mathrm{p} 53$ in $\mathrm{CoCl}_{2}$-induced autophagic death of glioma cells, human glioma DBTRG-05MG cells were further used as our experimental model (Fig. 7). Exposure of DBTRG-05MG cells to hypoxia led to a 3.6-fold induction of cell autophagy (Fig. 7A). Pretreatment with 3-MA did not affect autophagy of DBTRG-05MG cells but attenuated hypoxia-induced cell autophagy by $56 \%$. Administration of hypoxia induced apoptosis of DBTRG-05MG cells by $20 \%$ (Fig. 7B). In contrast, pretreatment of DBTRG-05MG cells with 3-MA did not affect cell apoptosis but caused a significant $60 \%$ reduction in hypoxia-induced apoptosis. Application of p53 siRNA into DBTRG-05MG cells for $24 \mathrm{~h}$ did not influence autophagy and apoptosis (Fig. 7C and D). However, when knocking down 553 translation in DBTRG-05MG cells, the hypoxia-induced autophagy and apoptosis were simultaneously reduced by 100 and 75\%, respectively (Fig. 7C and D). 
A
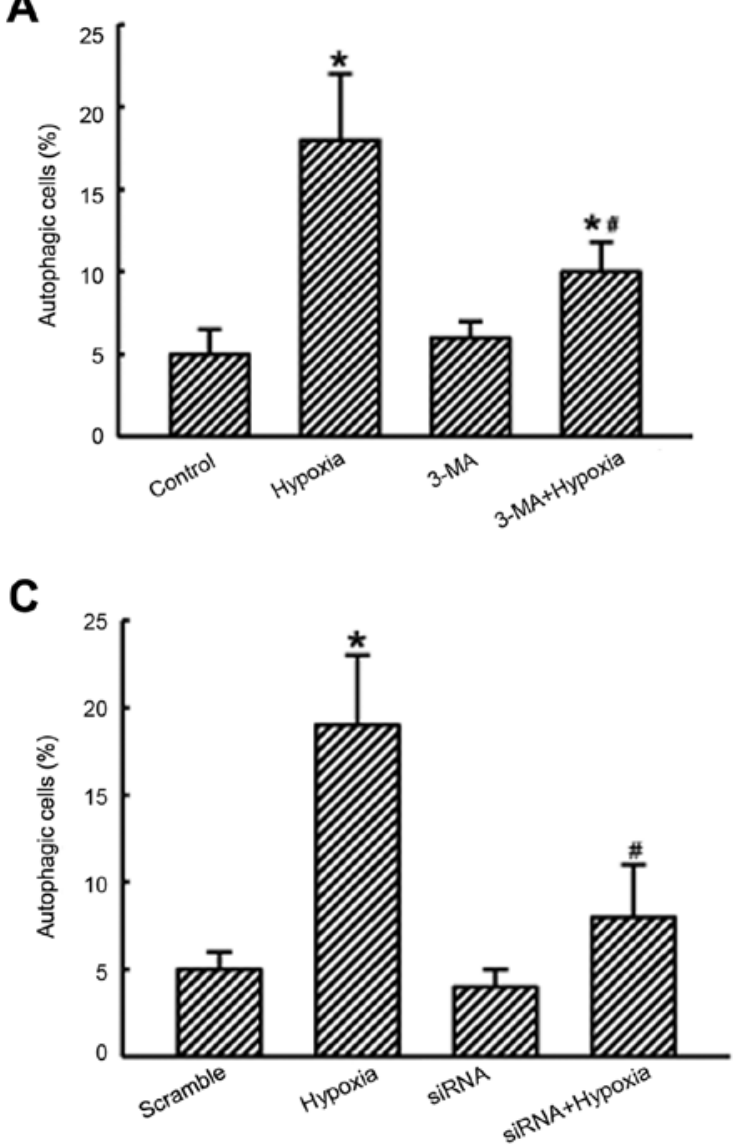

B

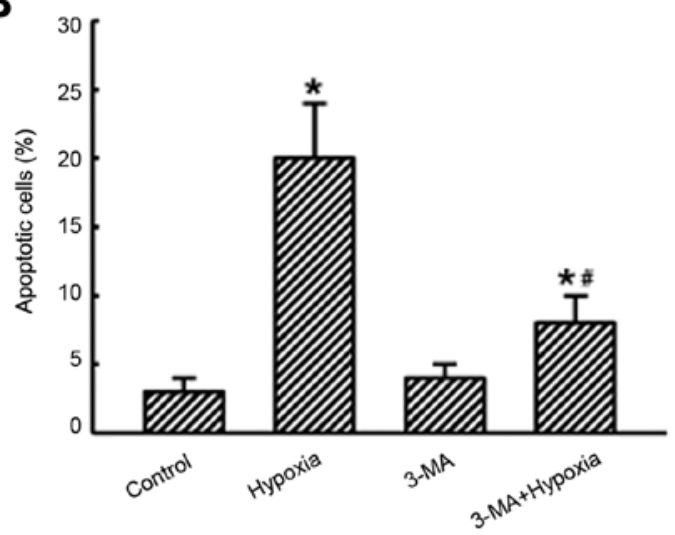

D

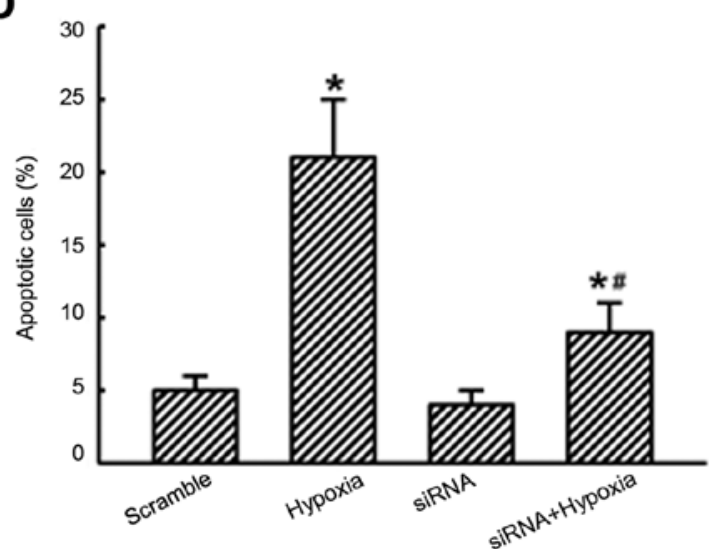

Figure 7. Participation of 553 in cobalt chloride $\left(\mathrm{CoCl}_{2}\right)$-induced autophagy and apoptosis in human glioma DBTRG-05MG cells. DBTRG-05MG cells were pretreated with 3-methyladenine (3-MA) for $1 \mathrm{~h}$ and then exposed to $100 \mu \mathrm{M} \mathrm{CoCl}_{2}$ for another $24 \mathrm{~h}$ (hypoxia) (A and B). Or, DBTRG-05MG cells were exposed to p53 siRNA (siRNA) for $24 \mathrm{~h}$ and then to $100 \mu \mathrm{M} \mathrm{CoCl}_{2}$ for another $24 \mathrm{~h}$ (hypoxia) (C and D). Scrambled siRNA was applied into control cells as the negative control (scramble). Cell autophagy (A and C) and cell apoptosis (B and D) were determined using flow cytometry. Each value represents the mean \pm SEM for $\mathrm{n}=6$. ${ }^{* * \#} \mathrm{p}<0.05$, values significantly differed from the control, hypoxia-, and $\mathrm{p} 53$ siRNA-treated groups, respectively.

\section{Discussion}

The present study showed that $\mathrm{CoCl}_{2}$ treatment can induce autophagy and subsequent death of human malignant glioma cells. Malignant gliomas are the most prevalent and aggressive brain tumors (2). In the clinic, patients suffering from malignant gliomas usually have poor prognoses, and their median overall survival rates are less than 1 year. Induction of hypoxia has recently been explored as a novel strategy for treating aggressive tumors such as cancer stem cells and chemotherapy-resistant tumor cells $(19,22)$. This study showed that administration of $\mathrm{CoCl}_{2}$ induced hypoxic stress in human glioma cells. Separately, exposure of human U87-MG cells to hypoxia triggered cell autophagy, apoptosis, and death. Interestingly, suppressing autophagy using the inhibitor, 3-MA, concurrently lessened hypoxia-induced apoptosis and death in human glioma U87-MG and DBTRG-05MG cells. Hence, $\mathrm{CoCl}_{2}$ treatment can induce autophagic death in human glioma cells. Brain hypoxia is thought to have bidirectional roles in controlling cell survival and death in human malignant glioma cells $(13,14)$. Hu et al reported that hypoxia-induced autophagy promotes glioblastoma cell survival (23). Nevertheless, our study provides in vitro data which demonstrate that delayed hypoxia can induce autophagy and autophagic death in human glioma cells. TMZ is an oral chemotherapeutic drug that is used to treat brain tumors (32). A previous study further showed that bortezomib induces cell death in GBM stem cells and TMZ-resistant glioma cells via a hypoxia-dependent mechanism (22). As a result, discovering a novel scheme to induce hypoxia may be beneficial for therapy of malignant gliomas and TMZ-resistant GBM through an autophagic apoptosis pathway.

Exposure to $\mathrm{CoCl}_{2}$ induces hypoxic insults to human glioma cells. In a hypoxic microenvironment, HIF-1 $\alpha$ is highly produced and functions as a transcription factor to regulate a large array of gene expressions in response to hypoxic conditions (9). Characteristically, HIF- $1 \alpha$ is recognized as a typical marker indicating that cells are experiencing hypoxia. Our present data revealed that $\mathrm{CoCl}_{2}$ treatment augmented amounts of HIF-1 $\alpha$ in human U87-MG cells. As to the mechanism, $\mathrm{CoCl}_{2}$ can diminish HIF-1 $\alpha$ degradation by suppressing prolyl-4-hydroxylase activity (33). Consequently, treatment of human glioma cells with $\mathrm{CoCl}_{2}$ can stimulate cellular hypoxic stress by means of enriching HIF-1 $\alpha$ expression. At the same time, exposure to hypoxia decreased the viability of human U87-MG cells. Brain hypoxia often occurs in brain neoplasms and traumatic brain injury and is recognized as a major cause of secondary injury to neurologically critically 
ill patients (8). With glioblastomas, hypoxia was reported to promote tumor survival and angiogenesis (23). In neuroblastoma cells, our previous study demonstrated that hypoxia can induce cell death via an apoptotic mechanism due to targeting antiapoptotic $b c l-x_{L}$ gene expression (12). The present study additionally proved the effects of hypoxia on triggering insults to human glioma cells.

$\mathrm{CoCl}_{2}$ treatment lessens the proliferation of human glioma U87-MG cells. Hypoxia broadly exists in diverse types of tumor microenvironments $(7,9)$. During tumorigenesis, low levels of oxygen may develop to promote tumor cell proliferation, angiogenesis, and metastasis through an HIF-1 $\alpha$-involved multifaceted network (34). Our present results showed that under extended hypoxic stress, incorporation of BrdU in human glioma U87-MG cells was repressed in concentration- and time-dependently. BrdU incorporation in cells can be measured to explain cell cycle processing in order to monitor the status of cell proliferation (35). Thus, this study demonstrated the suppressive effects of extended hypoxia on the proliferation of human glioma cells. In the clinic, rapid tumor growth because of speedy cell proliferation is one of major features and reasons illuminating the casual recurrence and poor prognoses of human malignant gliomas (4). Li et al reported that hypoxic conditions can activate a self-protective mechanism against glioma proliferation (36). As a result, $\mathrm{CoCl}_{2}$ treatment is able to prevent tumor cell proliferation and then suppress tumor growth and angiogenesis in human malignant gliomas.

$\mathrm{CoCl}_{2}$ treatment can induce autophagic insults to human glioma cells. Autophagy is a self-degradative process inside cells $(15,16)$. Autophagosomes, acidic vesicular organelles, and elevation in LC3-II levels are considered as consistent markers of cell autophagy $(37,38)$. Our preliminary study has shown that treatment of human U87-MG cells with $\mathrm{CoCl}_{2}$ could induce autophagosomes, acidic vesicular organelles, and LC3-II amounts. Herein, we demonstrated the concentrationand time-dependent effects of $\mathrm{CoCl}_{2}$ treatment on raising the proportions of human glioma cells with acidic vesicular organelles and the levels of LC3-II protein. Moreover, 3-MA and chloroquine are typically used as inhibitors of cell autophagy because it can block the formation of autophagosomes (39). Our current data showed the repressive effects of pretreatment with 3-MA and chloroquine on $\mathrm{CoCl}_{2}$-induced autophagy of human glioma cells. Separately, pretreatment with Rapa, an inducer of autophagy, synergistically amplified hypoxia-induced cell autophagy. Therefore, we provide several lines of evidence to show that delayed hypoxia can induce autophagy in human glioma cells. Nevertheless, autophagic cells can reverse course and survive or proceed to death $(23,24)$. This study showed that hypoxia decreased the viability of human U87-MG cells. Pretreatment with 3-MA and chloroquine caused concurrent defenses against $\mathrm{CoCl}_{2}$-induced cell death. Consequently, $\mathrm{CoCl}_{2}$ treatment can induce autophagy and autophagic death of human glioma cells. Bevacizumab is reported to kill highgrade gliomas via a hypoxia-induced autophagic pathway (19). Thus, induction of prolonged hypoxia has the potential to be a new therapeutic strategy for human gliomas.

Autophagy-induced apoptosis is involved in $\mathrm{CoCl}_{2}$ treatment-induced damage to human glioma cells. Exposure of human glioma U87-MG cells to $\mathrm{CoCl}_{2}$ induced caspase-3 activation and sequential cell cycle arrest at the sub- $\mathrm{G}_{1}$ phase. Caspase- 3 activation and cell cycle arrest at the sub- $\mathrm{G}_{1}$ phase are two typical characteristics indicating that cells are undergoing apoptosis $(40,41)$. Hence, $\mathrm{CoCl}_{2}$ treatment can induce apoptosis of human glioma U87-MG cells. Autophagy is reported to closely cross-talk with apoptosis (42). In general, autophagy can block apoptosis, and certain apoptosis-associated proteins disrupt the autophagic process. In some cases, autophagy may induce cell apoptosis or necrosis, known as autophagic cell death (42). This study demonstrated that pretreatment with 3-MA alone did not influence apoptosis of human U87-MG cells but caused significant alleviation of $\mathrm{CoCl}_{2}$-induced apoptotic injury. Thus, $\mathrm{CoCl}_{2}$ treatment can induce autophagic apoptosis in human glioma cells. The key principles of cancer therapy focus on inducing cell death and inhibiting cell proliferation (42). Our previous studies showed that honokiol, a polyphenol, induced autophagic apoptosis in neuroblastomas and gliomas $(21,25)$. The present study additionally supports hypoxia being applied to kill glioma cells via inducing cell autophagy and consequent autophagic apoptosis.

p53 participates in $\mathrm{CoCl}_{2}$-induced autophagic apoptosis in human glioma cells. p53, a tumor suppressor protein, can transcriptionally regulate expression of certain genes and then control cell survival or death (26). Also, p53 is reported to control cell autophagy by adjusting downstream damage-regulated autophagy modulator (DRAM) expression, a lysosomal protein $(10,40)$. This study showed that knocking down p53 expression using RNAi instantaneously attenuated $\mathrm{CoCl}_{2}$ induced autophagy and subsequent apoptosis. Our recent study proved that activation of p53 sequentially results in suppression of mammalian target of rapamycin (mTOR) activity and then induction of autophagy of glioma cells (10). Hence, p53 participates in $\mathrm{CoCl}_{2}$-induced cell autophagy in human glioma cells. Feng et al reported that p53 can upregulate unc-51-like kinase $1 / 2$, which are necessary for sustained autophagy in response to camptothecin-induced DNA damage (44). Furthermore, a previous study demonstrated the contribution of p53 to triggering cell autophagy and death by inducing DRAM gene expression (45). The present study indicated that co-treatment with 3-MA and p53 siRNA synergistically protected human glioma cells from $\mathrm{CoCl}_{2}$ treatment-induced caspase-3 activation, cell apoptosis, and cell death. As a result, p53 plays a crucial role in mediating hypoxia-induced cell autophagy and subsequent cell apoptosis in human gliomas.

In conclusion, this study verified the effects of $\mathrm{CoCl}_{2}$ in inducing hypoxic stress in human glioma U87-MG cells. In parallel, exposure to $\mathrm{CoCl}_{2}$ led to significant reductions in the viability and proliferation of human glioma cells. As to the mechanism, treatment of human U87-MG cells with $\mathrm{CoCl}_{2}$ meaningfully augmented levels of acidic vesicular autophagosomes and the cellular LC3-II protein. The gainand loss-of-function strategies further showed induction of autophagy in human glioma cells by $\mathrm{CoCl}_{2}$. Pretreatment with 3-MA and chloroquine decreased the proportion of human U87-MG cells undergoing autophagy and concurrently attenuated $\mathrm{CoCl}_{2}$-triggered caspase- 3 activation and cell apoptosis. Consecutively, knocking down p53 synthesis by RNAi could weaken hypoxia-induced cell autophagy, apoptosis, and death. In contrast, co-treatment with 3-MA and p53 siRNA synergistically protected human glioma cells against $\mathrm{CoCl}_{2}-$ 
induced autophagic death. The $\mathrm{CoCl}_{2}$-induced autophagic apoptosis were supplementarily confirmed in human glioma DBTRG-05MG cells. Taken together, $\mathrm{CoCl}_{2}$ treatment can induce autophagic apoptosis of human glioma cells via a p53-dependent pathway. Induction of delayed hypoxia may have the potential to be clinically applied for treating human malignant gliomas. An in vivo intracranial model is being investigated to confirm our in vitro findings on the suppressive effects of hypoxia on glioma growth through an autophagic apoptosis pathway.

\section{Acknowledgements}

This study was supported by grants from the Chi-Mei Medical Center (102CM-TMU-14-1), Wan-Fang Hospital (105-swf-04), and the Health and Welfare Surcharge of Tobacco Products (MOHW105-TDU-B-212-134001), Taiwan. The authors express their gratitude to Ms. Yi-Ling Lin for her technical support and data collection during the experiments.

\section{References}

1. Wacker MR, Hoshino T, Ahn DK, Davis RL and Prados MD: The prognostic implications of histologic classification and bromodeoxyuridine labeling index of mixed gliomas. J Neurooncol 19 113-122, 1994.

2. Jordan JT, Gerstner ER, Batchelor TT, Cahill DP and Plotkin SR: Glioblastoma care in the elderly. Cancer 122: 189-197, 2016.

3. Kalkan R: Hypoxia is the driving force behind GBM and could be a new tool in GBM treatment. Crit Rev Eukaryot Gene Expr 25: $363-369,2015$

4. Preusser M, Lim M, Hafler DA, Reardon DA and Sampson JH: Prospects of immune checkpoint modulators in the treatment of glioblastoma. Nat Rev Neurol 11: 504-514, 2015.

5. Curtin JF, Liu N, Candolfi M, Xiong W, Assi H, Yagiz K, Edwards MR, Michelsen KS, Kroeger KM, Liu C, et al: HMGB1 mediates endogenous TLR2 activation and brain tumor regression. PLoS Med 6: e10, 2009.

6. Gerstner ER, Duda DG, di Tomaso E, Ryg PA, Loeffler JS, Sorensen AG, Ivy P, Jain RK and Batchelor TT: VEGF inhibitors in the treatment of cerebral edema in patients with brain cancer. Nat Rev Clin Oncol 6: 229-236, 2009.

7. Freese KE, Kokai L, Edwards RP, Philips BJ, Sheikh MA, Kelley J, Comerci J, Marra KG, Rubin JP and Linkov F: Adiposederived stems cells and their role in human cancer development, growth, progression, and metastasis: A systematic review. Cancer Res 75: 1161-1168, 2015.

8. Lingsma HF, Roozenbeek B, Steyerberg EW, Murray GD and Maas AI: Early prognosis in traumatic brain injury: From prophecies to predictions. Lancet Neurol 9: 543-554, 2010.

9. Semenza GL: Surviving ischemia: Adaptive responses mediated by hypoxia-inducible factor 1. J Clin Invest 106: 809-812, 2000.

10. Lin CJ, Lin YL, Luh F, Yen Y and Chen RM: Preclinical effects of CRLX101, an investigational camptothecin-containing nanoparticle drug conjugate, on treating glioblastoma multiforme via apoptosis and antiangiogenesis. Oncotarget 7: 42408-42421, 2016.

11. Chan DA, Krieg AJ, Turcotte S and Giaccia AJ: HIF gene expression in cancer therapy. Methods Enzymol 435: 323-345, 2007.

12. Chio CC, Lin JW, Cheng HA, Chiu WT, Wang YH, Wang JJ, Hsing $\mathrm{CH}$ and Chen RM: MicroRNA-210 targets antiapoptotic Bcl-2 expression and mediates hypoxia-induced apoptosis of neuroblastoma cells. Arch Toxicol 87: 459-468, 2013.

13. Joseph JV, Conroy S, Pavlov K, Sontakke P, Tomar T, EggensMeijer E, Balasubramaniyan V, Wagemakers M, den Dunnen WF and Kruyt FA: Hypoxia enhances migration and invasion in glioblastoma by promoting a mesenchymal shift mediated by the HIF1 $\alpha$-ZEB1 axis. Cancer Lett 359: 107-116, 2015.

14. Sun W, Jelkmann W and Depping R: Prolyl-4-hydroxylase 2 enhances hypoxia-induced glioblastoma cell death by regulating the gene expression of hypoxia-inducible factor- $\alpha$. Cell Death Dis 5: e1322, 2014.
15. Codogno P, Mehrpour M and Proikas-Cezanne T: Canonical and non-canonical autophagy: Variations on a common theme of self-eating? Nat Rev Mol Cell Biol 13: 7-12, 2011.

16. Kaur J and Debnath J: Autophagy at the crossroads of catabolism and anabolism. Nat Rev Mol Cell Biol 16: 461-472, 2015.

17. Yoshimori T: Autophagy: A regulated bulk degradation process inside cells. Biochem Biophys Res Commun 313: 453-458, 2004.

18. Kondo Y, Kanzawa T, Sawaya R and Kondo S: The role of autophagy in cancer development and response to therapy. Nat Rev Cancer 5: 726-734, 2005.

19. Nanegrungsunk D, Onchan W, Chattipakorn $N$ and Chattipakorn SC: Current evidence of temozolomide and bevacizumab in treatment of gliomas. Neurol Res 37: 167-183, 2015.

20. Dolma S, Selvadurai HJ, Lan X, Lee L, Kushida M, Voisin V, Whetstone H, So M, Aviv T, Park N, et al: Inhibition of dopamine receptor D4 impedes autophagic flux, proliferation, and survival of glioblastoma stem cells. Cancer Cell 29: 859-873, 2016.

21. Lin CJ, Chen TL, Tseng YY, Wu GJ, Hsieh MH, Lin YW and Chen RM: Honokiol induces autophagic cell death in malignant glioma through reactive oxygen species-mediated regulation of the p53/PI3K/Akt/mTOR signaling pathway. Toxicol Appl Pharmacol 304: 59-69, 2016.

22. Bota DA, Alexandru D, Keir ST, Bigner D, Vredenburgh J and Friedman HS: Proteasome inhibition with bortezomib induces cell death in GBM stem-like cells and temozolomide-resistant glioma cell lines, but stimulates GBM stem-like cells' VEGF production and angiogenesis. J Neurosurg 119: 1415-1423, 2013.

23. Hu YL, DeLay M, Jahangiri A, Molinaro AM, Rose SD, Carbonell WS and Aghi MK: Hypoxia-induced autophagy promotes tumor cell survival and adaptation to antiangiogenic treatment in glioblastoma. Cancer Res 72: 1773-1783, 2012.

24. Xue H, Yuan G, Guo X, Liu Q, Zhang J, Gao X, Guo X, Xu S, Li T, Shao Q, et al: A novel tumor-promoting mechanism of IL6 and the therapeutic efficacy of tocilizumab: Hypoxia-induced IL6 is a potent autophagy initiator in glioblastoma via the p-STAT3MIR155-3p-CREBRF pathway. Autophagy 12: 1129-1152, 2016.

25. Yeh PS, Wang W, Chang YA, Lin CJ, Wang JJ and Chen RM: Honokiol induces autophagy of neuroblastoma cells through activating the PI3K/Akt/mTOR and endoplasmic reticular stress/ ERK1/2 signaling pathways and suppressing cell migration. Cancer Lett 370: 66-77, 2016.

26. Vousden KH and Lu X: Live or let die: The cell's response to p53. Nat Rev Cancer 2: 594-604, 2002.

27. Ho MH, Liao MH, Lin YL, Lai CH, Lin PI and Chen RM: Improving effects of chitosan nanofiber scaffolds on osteoblast proliferation and maturation. Int J Nanomed 9: 4293-4304, 2014.

28. Chang CY, Lui TN, Lin JW, Lin YL, Hsing CH, Wang JJ and Chen RM: Roles of microRNA-1 in hypoxia-induced apoptotic insults to neuronal cells. Arch Toxicol 90: 191-202, 2016.

29. Lee YE, Hong CY, Lin YL and Chen RM: MicroRNA-1 participates in nitric oxide-induced apoptotic insults to MC3T3-E1 cells by targeting heat-shock protein-70. Int J Biol Sci 11: 246-255, 2015.

30. Wu GJ, Wang W, Lin YL, Liu SH and Chen RM: Oxidative stress-induced apoptotic insults to rat osteoblasts are attenuated by nitric oxide pretreatment via GATA-5-involved regulation of Bcl-X L gene expression and protein translocation. Arch Toxicol 90: 905-916, 2016.

31. Wu TT, Tai YT, Cherng YG, Chen TG, Lin CJ, Chen TL, Chang HC and Chen RM: GATA-2 transduces LPS-induced il-1 $\beta$ gene expression in macrophages via a toll-like receptor 4/MD88/ MAPK-dependent mechanism. PLoS One 8: e72404, 2013.

32. Messaoudi K, Clavreul A and Lagarce F: Toward an effective strategy in glioblastoma treatment. Part II: RNA interference as a promising way to sensitize glioblastomas to temozolomide. Drug Discov Today 20: 772-779, 2015.

33. Kaelin WG Jr and Ratcliffe PJ: Oxygen sensing by metazoans: The central role of the HIF hydroxylase pathway. Mol Cell 30: 393-402, 2008

34. Mamlouk S and Wielockx B: Hypoxia-inducible factors as key regulators of tumor inflammation. Int J Cancer 132: 2721-2729, 2013.

35. Kajita K, Mori I, Kitada Y, Taguchi K, Kajita T, Hanamoto T, Ikeda T, Fujioka K, Yamauchi M, Okada H, et al: Small proliferative adipocytes: Identification of proliferative cells expressing adipocyte markers. Endocr J 60: 931-939, 2013. 
36. Li W, Winters A, Poteet E, Ryou MG, Lin S, Hao S, Wu Z, Yuan F, Hatanpaa KJ, Simpkins JW, et al: Involvement of estrogen receptor $\beta 5$ in the progression of glioma. Brain Res 1503: 97-107, 2013.

37. Mizushima N, Yoshimori $\mathrm{T}$ and Levine B: Methods in mammalian autophagy research. Cell 140: 313-326, 2010

38. Klionsky DJ, Abdelmohsen K, Abe A, Abedin MJ, Abeliovich H, Acevedo Arozena A, Adachi H, Adams CM, Adams PD, Adeli K, et al: Guidelines for the use and interpretation of assays for monitoring autophagy (3rd edition). Autophagy 12: 1-222, 2016.

39. Wu YT, Tan HL, Shui G, Bauvy C, Huang Q, Wenk MR, Ong CN, Codogno P and Shen HM: Dual role of 3-methyladenine in modulation of autophagy via different temporal patterns of inhibition on class I and III phosphoinositide 3-kinase. J Biol Chem 285: 10850-10861, 2010.

40. Chen $\mathrm{N}$ and Karantza-Wadsworth V: Role and regulation of autophagy in cancer. Biochim Biophys Acta 1793: 1516-1523, 2009.
41. Galluzzi L, Kepp O and Kroemer G: Caspase-3 and prostaglandins signal for tumor regrowth in cancer therapy. Oncogene 31 2805-2808, 2012

42. Mariño G, Niso-Santano M, Baehrecke EH and Kroemer G: Self-consumption: The interplay of autophagy and apoptosis. Nat Rev Mol Cell Biol 15: 81-94, 2014.

43. Sui X, Chen R, Wang Z, Huang Z, Kong N, Zhang M, Han W, Lou F, Yang J, Zhang Q, et al: Autophagy and chemotherapy resistance: A promising therapeutic target for cancer treatment. Cell Death Dis 4: e838, 2013.

44. Feng Z, Zhang H, Levine AJ and Jin S: The coordinate regulation of the p53 and mTOR pathways in cells. Proc Natl Acad Sci USA 102: 8204-8209, 2005.

45. Crighton D, Wilkinson S, O'Prey J, Syed N, Smith P, Harrison PR, Gasco M, Garrone O, Crook T and Ryan KM: DRAM, a p53-induced modulator of autophagy, is critical for apoptosis. Cell 126: 121-134, 2006. 